\title{
NGHIÊN CÚU NGUY CƠ GÃY XƯƠNG THEO MÔ HÌNH FRAX TRÊN ĐỐI TƯợNG NỮ THỪA CÂN - BÉO PHÌ TRÊN 45 TUỔI \\ Luu Ngọc Giang ${ }^{1}$, Lê Anh Thu ${ }^{2}$, Nguyễn Hải Thủy ${ }^{I}$ \\ ${ }^{I}$ Truoòng Đại học Y Dược Huế; ${ }^{2}$ Hội loãng xương TP. Hồ Chí Minh
}

\section{ABSTRACT \\ Risk of bone fractures according to \\ FRAXModel in overweight//obese women over 45 years old}

Objectives: To investigate the risk of bone fractures in overweight/Obese women. Subjects and research methods: 207 women in 2 groups (1) 147 overweight/obese (BMI $\geq$ $23 \mathrm{~kg} / \mathrm{m} 2$ ) and (2) 60 is normalweight (BMI $<23 \mathrm{~kg} / \mathrm{m} 2)$. Measure bone mineral density (BMD) by DEXA method and assess fracture risk according to Fracture Risk Assessment Tool (FRAX) model. Results: BMD in the overweight/Obese group is higher than the normal group $(0.64 \pm 0.11$ compared to 0.60 $\pm 0.12), \mathrm{p}<0.05$. - The prevalence of osteoporosis and osteopenia in the femoral neck (FN) of overweight/obese group is $27.9 \%$ and $50.3 \%$, respectively, the normal group is $45.0 \%$ and $43.3 \%$. - The rate of osteoporosis and osteopenia in the lumbar spine (LS) of the overweight/Obese group is $45.6 \%$ and $34.7 \%$, respectively, the normal group is $48.3 \%$ and $43.4 \%$.- The rate of osteoporosis in the overweight/Obese group is low than the normal group by assessing the $\mathrm{T}$ index in the FN (27.9\% and $45.0 \%)$, p $<0.05$. Predict the risk of bone fractures according to FRAX.- The probability of total fracture in 10 years $\geq 20 \%$ accounts for $1 \%$ and the probability of femoral neck fracture in 10 years $\geq 3 \%$ accounts for $20.3 \%$. - The rate of general osteoporosis in $\mathrm{FN}$ is $32.9 \%$ and the rate indicated for Osteoporosis treatment is recommended by NOF is $45 \%$. Conclusions: The bone density of overweight/obese women is not reduced but still at risk of bone fractures.

Key words: Measure bone mineral density (BMD), Fracture Risk Assessment Tool (FRAX) model

\section{TÓM TẮT}

Mục tiêu: Khảo sát nguy cơ gãy xương phụ nữ thừa cân béo phì. Đối tượng và phương pháp nghiên cứu: 207 phụ nữ chia 2 nhóm (1) 147 người có thừa cân/ béo phì (BMI $\geq 23 \mathrm{~kg} / \mathrm{m}^{2}$ ) và (2) 60 không thừa cân, béo phì $\left(\mathrm{BMI}<23 \mathrm{~kg} / \mathrm{m}^{2}\right)$. Đo mật độ xương bằng phương pháp DEXA và đánh giá nguy cơ gãy xương theo mô hình FRAX. Kết quả: Mật độ xương. - MĐX CXĐ ở nhóm thừa cân béo phì cao hơn so với nhóm bình thường $(0,64 \pm 0,11$ so với $0,60 \pm 0,12), p<0,05$. - Tỷ lệ loãng xương và thiếu xương tại $\mathrm{CXÐ} \mathrm{của} \mathrm{nhóm} \mathrm{thừa} \mathrm{cân}$ béo phì tương ứng là $27,9 \%$ và $50,3 \%$, nhóm bình thường tương ứng là $45,0 \%$ và $43,3 \%$. Tỷ lệ loãng xương và thiếu xương tại CSTL của nhómthừa cân béo phì tương ứng là $45,6 \%$ và $34,7 \%$, nhóm bình thường tương ứng là $48,3 \%$ và $43,4 \%$. - Tỷ lệ loãng xương ở nhóm thừa cân béo phì thấp hơn so với nhóm bình thường qua đánh giá chỉ số $\mathrm{T}$ ở $\mathrm{CXĐ}(27,9 \%$ và $45,0 \%), \mathrm{p}<0,05$. Dự báo nguy cơ gãy xương theo mô hình FRAX.- Xác suất gãy xương toàn thân trong 10 năm $\geq 20 \%$ chiếm tỷ lệ $1 \%$ và gãy cổ xương đùi trong 10 năm $\geq 3 \%$ chiếm tỷ lệ 20,3\%. - Tỷ lệ loãng xương chung tại CXĐ là $32,9 \%$ và tỷ lệ có chỉ định điều trị $\mathrm{LX}$ theo khuyến cáo của NOF là $45 \%$. Kết luận: Mật độ xương phụ nữ thừa cân béo phì khồng giảm nhưng vẫn có nguy cơ gãy xương.

Tù khóa: mật độ xương, dự báo nguy co' gãy xương

Chịu trách nhiệm chính: Lưu Ngọc Giang

Ngày nhận bài: 15/11/2019

Ngày phản biện khoa học: 20/12/2019

Ngày duyệt bài: 31/12/2019

\section{1. ĐẠTT VẤN ĐỀ}

Béo phì là bệnh rối loạn chuyển hóa đã và đang trở thành một trong những bệnh lý không lây nhiểm phổ biến trên toàn thế giới . Loãng xương là một rối loạn chuyển hoá của xương 
gây tổn thương sức mạnh của xương dẫn đến tăng nguy cơ gãy xương. Loãng xương là nguyên nhân phổ biến nhất gây gãy xương nhất là phụ nữ . Nhiều bằng chứng cho thấy mô mỡ có tác động xấu đến sức mạnh của xương, kết luận này ngược lại với những nghiên cứu trước đây là mô mỡ đóng vai trò bảo vệ xương. Mô mỡ không chỉ là một kho năng lượng đơn thuần mà mô mỡ còn tiết ra một số adipokine và các yếu tố viêm làm thay đồi quá trình tái hấp thu xương. Ngoài ra, những năm gần đây nhiều nghiên cứu đã kết luận insulin có tác dụng trực tiếp lên tế bào xương. Tuy nhiên, do sự liên quan chặt chẽ giữa béo phì và kháng insulin nên khó phân biệt các tác động độc lập của bệnh béo phì và kháng insulin trên xương. Một số nghiên cứu kết luận có mối liên quan giữa nồng độ insulin trong máu và mật độ xương, độc lập với BMI [1]. Ngược lại, một số nghiên cứu khác cho thây mất mối liên quan giữa insulin và $\mathrm{MĐX}$ sau khi điều chỉnh $\mathrm{BMI}$, kháng insulin có thể ảnh hưởng đến $\mathrm{MĐX}$ thông qua các tác động gián tiếp, ví dụ như trọng lượng cơ thể . Một số nghiên cứu cho thấy không liên quan [2] hoặc thậm chí là mối liên quan nghịch giữa kháng insulin và $\mathrm{MĐX} \mathrm{[3].}$

Mặc khác, những thay đồi liên quan đến tuổi trong thành phần cơ thể, các yếu tố trao đổi chất, giảm mức độ hormon sau mãn kinh, kèm theo giảm hoạt động thể lực... tất cả là nguyên nhân của xu hướng tăng cân ở phụ nữ lớn tuổi, được biểu hiện bởi tăng khối lượng chất béo và giảm khối lượng nạc là nguyên nhân làm tăng nguy cơ béo phì và loãng xương. Ở Việt Nam đã có nhiều nghiên cứu về béo phì, kháng insulinvà mật độ xương nhưng chưa có nghiên cứu về mối liên quan giữa kháng insulin và mật độ xương ở phụ nữ trên 45 tuổi thừa cân, béo phì. Mục tiêu nghiên cứu: Dư báo nguy cơ gãy xuơng theo mô hìn FRAX ở đối tượng nữ thì cân béo phì sau 45 tuổi.

\section{2. ĐỐI TƯợNG VÀ PHƯỠNG PHÁP NGHIÊN CỨU}

2.1. Đối tượng nghiên cứu

2.1.1. Tiêu chuẩn chọn mẫu: Đối tượng thỏa các tiêu chuẩn sau:
- Phụ nữ trên 45 tuổi.

- Nhóm bệnh: BMI $\geq 23 \mathrm{~kg} / \mathrm{m}^{2}$

- Nhóm chứng: $\mathrm{BMI}<23 \mathrm{~kg} / \mathrm{m}^{2}$. (làm

nhóm chứng hay nhóm quy chiếu).

Gồm 207 người chia 2 nhóm:

- Nhóm bệnh: 147 người có thừa cân béo phì $\left(\mathrm{BMI} \geq 23 \mathrm{~kg} / \mathrm{m}^{2}\right)$

- Nhóm chứng: 60 không thừa cân, béo phì $\left(\mathrm{BMI}<23 \mathrm{~kg} / \mathrm{m}^{2}\right)$

\subsection{Phương pháp nghiên cứu}

\subsubsection{Phương pháp nghiên cúu}

Mô tả cắt ngang, so sánh với nhóm chứng

2.2.2. Phương pháp chọn mẫu

- Chọn mẫu thuận tiện thời gian từ tháng 1/2017 đến tháng 6/2018.

\subsubsection{Các biến số nghiên cúu}

2.2.3.1. Tuổi: dựa vào năm sinh để tính tuổi và chia 2 nhóm:

- Nhóm 1: $45<$ và $\leq 59$ tuổi

- Nhóm 2: $\geq 60$ tuổi

2.2.3.2. Đo mật độ xưong bằng phưong pháp DEXA

- Phương tiện: Được thực hiện bằng máy Discovery $\mathrm{Ci}$ do hãng Hologic (Mỹ) sản xuất 2017, tại Khoa Chẩn đoán hình ảnh, Phòng khám Đa khoa Medic - Bình dương.

- Hệ số biến thiên của máy DEXA là 1,8\% ở cột sống thắt lưng và $1,5 \%$ ở xương đùi. Máy được chuẩn hóa bằng cách đo mật độ xương của một mô hình chuẩn có $\mathrm{MĐX}$ là $1 \mathrm{~g} / \mathrm{cm}^{2}$ vào đầu buổi sáng và chiều.

- Máy DEXA tại Phòng khám Đa khoa Medic - Bình dương sử dụng các thông số tham chiếu của dân số nữ, Nhật Bản tính cho người Châu Á. Do các giá trị tham chiếu của người Việt Nam vẫn đang trong quá trình xây dựng và chưa được công nhận nên chúng tôi sử dụng các giá trị do Hologic cung cấp.

- Vị trí đo: cổ xương đùi và cột sống thắt lưng.

- Đánh giá kết quả: Mật độ xương vùng cột sống thắt lưng là trung bình của mật độ xương đo ở các đốt sống L1, L2, L3, L4. Mật độ xương cổ xương đùi là mật độ xương đo ngay tại vị trí cổ xương đùi không tính mật độ xương đo tại mấu chuyển lớn, liên mấu chuyển và tam giác Ward. Chẩn đoán loãng xương dựa vào Tiêu chuẩn chẩn đoán loãng xương (WHO 1994). 
Bảng 2.1. Chẩn đoán loãng xương dựa vào chỉ số T [44].

\begin{tabular}{|l|l|}
\hline \multicolumn{1}{|c|}{ Chỉ số $\mathbf{T}(\mathbf{T})$} & \multicolumn{1}{|c|}{ Phân loại chấn đoán } \\
\hline $\mathrm{T}>-1$ & Bình thường \\
\hline $\mathrm{T} \leq-1$ đến $\mathrm{T}>-2,5$ & Thiếu xương (Osteopenia) \\
\hline $\mathrm{T} \leq-2,5$ & Loãng xương (Osteoporosis) \\
\hline $\mathrm{T} \leq-2,5$ kèm có tiền sử gãy xương & Loãng xương nặng (Severe osteoporosis) \\
\hline
\end{tabular}

Với: 1T: 1 độ lệch chuẩn trên giá trị cột sống thắt lưng cũng được tính là có tiền sử trung bình của người trẻ, khỏe.

-1T: 1 độ lệch chuẩn dưới giá trị trung bình của người trẻ, khỏe

\subsubsection{Mô hình FRAX}

Các dữ liệu của mô hình FRAX liên quan đến lối sống, tiền sử gãy xương, tiền sử sử dụng thuốc .... được thu nhập bằng một bộ câu hỏi. Ngoài ra mỗi cá nhân được đo mật độ xương bằng máy $\mathrm{DEXA}$ Hologic Discovery $\mathrm{Ci}$ với giá trị tham chiếu của dân số nữ Nhật Bản sử dụng cho người Châu Á. Sau đó nhập các dữ liệu vào phần mềm mô hình FRAX trực tuyến theo địa chỉ https://www.sheffield.ac.uk/FRAX/tool.aspx. Các dữ liệu bao gồm:

1. Tuổi: Mô hình FRAX chỉ chấp nhận tuổi từ 40 đến 90 , nếu ngoài độ tuổi này kết quả được tính như độ tuổi từ 40 - 90 .

2. Giới: Nam hoặc nữ. Các đối tượng trong nghiên cứu này đều là nữ.

3. Cân nặng: đơn vị kg

4. Chiều cao: đơn vị cm

5. Tiền sử gãy xương: được xem là có nếu tiền sử có gãy xương trên lâm sàng, Gãy xương cột sống được phát hiện trên $\mathrm{X}$ quang gãy xương.

6. Chỉ số T: chọn máy DEXA đang sử dụng và nhập vào chỉ số $\mathrm{T}$ cổ xương đùi.

7. Tiền sử gãy cổ xương đùi của bố hoặc mẹ: Hỏi tiền sử gãy xương đùi ở bố hoặc mẹ của bệnh nhân. Nhập vào có hoặc không.

8. Hút thuốc: Nhập vào có hoặc không. Có hút thuốc lá khi đang hút thuốc lá, đã từng hút thuốc lá (ngưng hút thuốc $\leq 1$ năm trước thời điểm nghiên cứu). Không hút khi chưa từng hút hoặc đã từng hút nhưng ngưng thuốc lá trên 1 năm trước thời điểm nghiên cứu.

9. Uống rượu: Nhập vào có nếu uống $\geq 3$ đơn vị rượu / ngày.

10. Viêm khớp dạng thấp: Nhập vào có khi có bằng chứng lâm sàng hoặc xét nghiệm chẩn đoán xác định viêm khớp dạng thấp.

11. Loãng xương thứ phát: Nhập có nếu bệnh nhân có các nguyên nhân gây loãng xương thứ phát.

12. Sử dụng corticoid: Nhập có nếu bệnh nhân hiện đang hoặc đã uống corticoid trong thời gian $\geq 3$ tháng với liều $\geq 5 \mathrm{mg} /$ ngày[4].

\subsubsection{Xü̉ lý số liệu}

- Xử lý số liệu phần mềm SPSS 22.0

\section{KẾT QUẢ}

\subsection{Mật độ xương}

\begin{tabular}{|c|c|c|c|}
\multicolumn{5}{|c}{ Bảng 3.1. Mật độ xương tại cột sống thắt lung } \\
\hline Vị trí & $\begin{array}{c}\text { Nhóm bệnh } \\
(\mathbf{n = 1 4 7})\end{array}$ & $\begin{array}{c}\text { Nhóm chứng } \\
(\mathbf{n = 6 0 )}\end{array}$ & $\mathbf{p}$ \\
\hline L1 & $0,75 \pm 0,13$ & $0,72 \pm 0,13$ & $>0,05$ \\
\hline L2 & $0,77 \pm 0,14$ & $0,74 \pm 0,15$ & $>0,05$ \\
\hline L3 & $0,82 \pm 0,16$ & $0,77 \pm 0,16$ & $>0,05$ \\
\hline L4 & $0,84 \pm 0,15$ & $0,79 \pm 0,17$ & $<0,05$ \\
\hline Trung bình & $0,80 \pm 0,14$ & $0,76 \pm 0,15$ & $>0,05$ \\
\hline
\end{tabular}

Mật độ xương trung bình tại cột sống thắt lưng của nhóm bệnh cao hơn nhóm chứng ( $\mathrm{p}>0,05)$. Mật độ xương tại vị trí L4 của nhóm bệnh cao hơn nhóm chứng $(\mathrm{p}<0,05)$. 
Bảng 3.2. Mật độ xương tại cổ xương đùi

\begin{tabular}{|c|c|c|c|}
\hline Vị trí & $\begin{array}{c}\text { Nhóm bệnh } \\
(\mathbf{n = 1 4 7})\end{array}$ & $\begin{array}{c}\text { Nhóm chứng } \\
(\mathbf{n}=\mathbf{6 0})\end{array}$ & $\mathbf{p}$ \\
\hline Cố xương đùi & $0,64 \pm 0,11$ & $0,60 \pm 0,12$ & $<\mathbf{0 , 0 5}$ \\
\hline
\end{tabular}

Mật độ xương tại cổ xương đùi của nhóm bệnh cao hơn nhóm chứng $(\mathrm{p}<0,05)$.

Bảng 3.3. Phân loại mật độ xương tại cột sống thắt lung

\begin{tabular}{|c|c|c|c|c|c|}
\hline \multirow[t]{2}{*}{ Phân loại } & \multicolumn{2}{|c|}{$\begin{array}{c}\text { Nhóm bệnh } \\
(n=147)\end{array}$} & \multicolumn{2}{|c|}{$\begin{array}{l}\text { Nhóm chứng } \\
\qquad(n=60)\end{array}$} & \multirow[t]{2}{*}{$\mathbf{p}$} \\
\hline & $\mathbf{n}$ & $\%$ & $\mathbf{n}$ & $\%$ & \\
\hline $\begin{array}{l}\text { Bình thường } \\
\text { (Chỉ số } T>-1 \text { ) }\end{array}$ & 29 & 19,7 & 5 & 8,3 & \multirow{3}{*}{$\begin{array}{c}\square^{\square} \square \square \\
, 30 \\
p>0,05\end{array}$} \\
\hline $\begin{array}{c}\text { Thiếu xương } \\
(-2,5<\text { Chỉ số } \mathrm{T} \leq-1)\end{array}$ & 51 & 34,7 & 26 & 43,4 & \\
\hline $\begin{array}{c}\text { Loãng xương } \\
\text { (Chỉ số } \mathrm{T} \leq-2,5 \text { ) }\end{array}$ & 67 & 45,6 & 29 & 48,3 & \\
\hline Tổng & 147 & 100 & 60 & 100 & \\
\hline $\mathrm{p}$ & \multicolumn{2}{|c|}{$<0,05$} & \multicolumn{2}{|c|}{$<0,05$} & \\
\hline
\end{tabular}

- Nhóm bệnh: Tỷ lệ thiếu xương là 34,7\% và tỷ lệ loãng xương là 45,6\% (p<0,05).

- Nhóm chứng: Tỷ lệ thiếu xương là $43,4 \%$ và tỷ lệ loãng xương là $48,3 \%(\mathrm{p}<0,05)$.

- Không có sự khác biệt về tỷ lệ thiếu xương và loãng xương giữa nhóm bệnh và nhóm chứng $(\mathrm{p}>0,05)$.

Bảng 3.4. Phân loại mật độ xương tại cổ xương đùi

\begin{tabular}{|c|c|c|c|c|c|}
\hline \multirow{2}{*}{ Phân loại } & \multicolumn{2}{|c|}{$\begin{array}{c}\text { Nhóm bệnh } \\
(n=147)\end{array}$} & \multicolumn{2}{|c|}{$\begin{array}{c}\text { Nhóm chứng } \\
(\mathrm{n}=60)\end{array}$} & \multirow{2}{*}{$\mathbf{p}$} \\
\hline & $\mathrm{n}$ & $\%$ & $\mathrm{n}$ & $\%$ & \\
\hline $\begin{array}{l}\text { Bình thường } \\
\text { (Chỉ số } \mathrm{T}>-1 \text { ) }\end{array}$ & 32 & 21,8 & 7 & 11,7 & \multirow{3}{*}{$\begin{array}{c}\square^{\square} \square \square \square, 53 \\
\mathbf{p}<\mathbf{0 , 0 5}\end{array}$} \\
\hline $\begin{array}{c}\text { Thiếu xương } \\
(-2,5<\text { Chỉ số } \mathrm{T} \leq-1)\end{array}$ & 74 & 50,3 & 26 & 43,3 & \\
\hline $\begin{array}{l}\text { Loãng xương } \\
\text { (Chỉ số } \mathrm{T} \leq-2,5 \text { ) }\end{array}$ & 41 & 27,9 & 27 & 45,0 & \\
\hline Tổng & 147 & 100 & 60 & 100 & \\
\hline $\mathrm{p}$ & \multicolumn{2}{|c|}{$<0,05$} & \multicolumn{2}{|c|}{$<0,05$} & \\
\hline
\end{tabular}

- Nhóm bệnh: Tỷ lệ thiếu xương là 50,3\% và loãng xương là 27,9\% (p<0,05).

- Nhóm chứng: Tỷ lệ thiếu xương là 43,3\% và loãng xương là $45,0 \%(\mathrm{p}<0,05)$.

* Có sự khác biệt có ý nghĩa thống kê về tỷ lệ thiếu xương và loãng xương giữa nhóm bệnh và nhóm chứng. Tóm lại tỷ lệ loãng xương chung tại $\mathrm{CXÐ} \mathrm{là} 32,9 \%$ và tỷ lệ có chỉ định điều trị LX theo khuyến cáo của NOF là $45 \%$.

Bảng 3.5. Tần suất các yếu tố nguy co trong mô hình FRAX

\begin{tabular}{|l|c|c|c|c|}
\hline \multicolumn{2}{|c|}{ Các yếu tố nguy co } & $\begin{array}{c}\text { CHUNG } \\
\text { n ( \%) }\end{array}$ & $\begin{array}{c}\text { NCGX TT } \\
\text { n ( \%) }\end{array}$ & $\begin{array}{c}\text { NCGX ĐÙI } \\
\text { n }(\boldsymbol{\%})\end{array}$ \\
\hline $\begin{array}{l}\text { Tuổi } \\
\text { (năm) }\end{array}$ & $45<$ và $\leq 59$ & $103(49,7)$ & $0(0,0)$ & $3(1,4)$ \\
\cline { 2 - 5 } & $\geq 60$ & $104(50,3)$ & $2(1,0)$ & $39(18,8)$ \\
\hline
\end{tabular}




\begin{tabular}{|c|c|c|c|}
\hline Tống & $207(100)$ & $2(1,0)$ & $42(20,3)$ \\
\hline Giới (Nữ) & $207(100)$ & $2(1,0)$ & $42(20,3)$ \\
\hline Trọng lượng (kg) & $57,99 \pm 8,74$ & $54,0 \pm 1,41$ & $54,71 \pm 7,47$ \\
\hline Chiều cao $(\mathrm{cm})$ & $152,71 \pm 5,20$ & $144,50 \pm 6,36$ & $144,50 \pm 6,36$ \\
\hline Tiền sử gãy xương & $22(10,6)$ & & \\
\hline TS gãy CXĐ của bố hoặc mẹ & $1(0,5)$ & & \\
\hline Hút thuốc lá & 0 & & \\
\hline Tiền sử sử dụng corticoid & 0 & & \\
\hline Viêm khớp dạng thấp & 0 & & \\
\hline Loãng xương thứ phát & 0 & & \\
\hline Uống rượu & 0 & & \\
\hline $\begin{array}{l}\text { Chỉ số } \mathrm{T}(\mathrm{CXÐ)} \\
+ \text { Bình thường }(\mathrm{T}>-1) \\
\text { + Thiếu xương }(-2,5<\mathrm{T} \leq-1) \\
\text { +Loãng xương }(\mathrm{T} \leq-2,5)\end{array}$ & $\begin{array}{c}39(18,8) \\
100(48,3) \\
68(32,9)\end{array}$ & $\begin{array}{c}0(0,0) \\
0(0,0) \\
2(1)\end{array}$ & $\begin{array}{c}0(0,0) \\
2(1,0) \\
40(19,3)\end{array}$ \\
\hline
\end{tabular}

- Nguy cơ cao: 42 đối tượng có nguy cơ gãy cổ xương đùi trong10 năm $\geq 3 \%$ và 2 đối tượng có nguy cơ gãy xương toàn thân trong 10 năm $\geq 20 \%$.

- Trong 42 đối tượng có nguy cơ gãy cổ xương đùi trong 10 năm $\geq 3 \%$ có 39 đối tượng $\geq 60$ tuổi, 3 đối tượng trong độ tuổi $45<$ và $\leq 59$.

- Hai đối tượng có nguy cơ gãy xương toàn thân trong 10 năm $\geq 20 \%$ đều $\geq 60$ tuổi.

- Có 2 đối tượng có nguy cơ gãy cổ xương đùi trong 10 năm $\geq 3 \%$ và thiếu xương.

- Có 22 đối tượng có tiền sử gãy xương và 1 đối tượng có tiền sử gãy $C X Đ$ của bố hoặc mẹ.

- Tất cả các đối tượng đều không hút thuốc lá, không tiền sử sử dụng thuốc glucocorticoid, không viêm khớp dạng thấp, không loãng xương thứ phát và không uống rượu.

- Tỷ lệ loãng xương là 32,9\% và tỷ lệ thiếu xương chung là 48,3\% .

Bảng 3.6. Dư báo nguy co cao theo mô hình FRAX

\begin{tabular}{|c|c|c|}
\hline Xác xuất gãy xương & Số lượng & Tỷ lệ \% \\
\hline Toàn thân $\geq 20 \%$ & 2 & 1,0 \\
\hline Cố xương đùi $\geq 3 \%$ & 42 & 20,3 \\
\hline
\end{tabular}

Xác suất gãy xương toàn thân trong 10 năm $\geq 20 \%$ có 2 đối tượng, chiếm tỷ lệ $1 \%$.

Xác suất gãy cổ xương đùi trong 10 năm $\geq 3 \%$ có 42 đối tượng, chiếm tỷ lệ $20,3 \%$.

\section{BÀN LUẦN \\ 4.1. Mật độ xương \\ lung \\ 4.1.1. Mật độ xưong tại cột sống thắt}

Mật độ xương tại cột sống thắt lưng là trung bình của mật độ xương tại các vị trí $\mathrm{L} 1$, L2, L3, L4. Mật độ xương trung bình tại cột sống thắt lưng nhóm bệnh là $(0,80 \pm 0,14)$ và nhóm chứng là $(0,76 \pm 0,15)$. Chúng tôi nhận thấy mật độ xương tại cột sống thắt lưng nhóm bệnh cao hơn nhóm chứng, sự khác biệt không có ý nghĩa thống kê .

Kết quả nghiên cứu của Kim K.C. và cộng sự, ở 907 phụ nữ Hàn quốc mãn kinh khỏe mạnh đã chứng minh rằng tỉ lệ mỡ trong cơ thể và vòng bụng có liên quan đến mật độ xương thấp và là nguy cơ cao cho gãy xương cột sống [5]. Nghiên cứu của Greco E.A.và cộng sự cho thấy những người béo phì có $\mathrm{MĐX}$ cột sống thắt lưng thấp đáng kể so với những người không béo phì cùng độ tuổi [6]. Kết quả nghiên cứu của Kim K.C. và Greco E.A. đều không tương đồng với kết quả của chúng tôi có thể do sự khác biệt về cõ mẫu hoặc chủng tộc.

Trong nghiên cứu của chúng tôi mặc dù ghi nhận mật độ xương tại cột sống thắt lưng nhóm bệnh cao hơn nhóm chứng tuy nhiên 
do sự khác biệt này không có ý nghĩa thống kê $(\mathrm{p}>0,05)$.

\subsubsection{Mật độ xuong tại cổ xuong đùi}

Mật độ xương tại cổ xương đùi nhóm bệnh là $(0,64 \pm 0,11)$ và nhóm chứng là $(0,60 \pm$ $0,12)$. Chúng tôi nhận thấy mật độ xương tại cổ xương đùi nhóm bệnh cao hơn nhóm chứng, có ý nghĩa thống kê .

Søgaard A.J. và cộng sự nghiên cứu trên 19.918 nữ và 23.061 nam trong độ tuổi 60 79 , được theo dõi trong thời gian trung bình là 8.1 năm. Các tác giả kết luận béo phì (tính theo BMI) có liên quan đến tăng nguy cơ gãy cổ xương đùi [7].

Hiện nay nhiều bằng chứng cho thấy mô mỡ có tác động tiêu cực đến sức mạnh của xương. Mô mỡ không chỉ là một kho năng lượng đơn thuần mà mô mỡ còn tiết ra một số adipokine và các yếu tố viêm làm thay đổi quá trình tái hấp thu xương. Nhiều kết quả nghiên cứu kết luận béo phì có liên quan đến những rối loạn mãn tính như hội chứng chuyển hóa, rối loạn chuyển hoá lipid máu và tiểu đường týp 2, làm giảm sức mạnh của xương và gia tăng nguy cơ gãy xương ở người béo phì [8]. Vì thế mối liên quan MĐX và $\mathrm{BMI}$ rất phức tạp, cần đánh giá mối liên quan này thông qua các adipokine và các yếu tố viêm được tiết ra từ mô mõ̃.

Trong nghiên cứu của chúng tôi mật độ xương tại cổ xương đùi nhóm bệnh cao hơn nhóm chứng, không phù hợp với những kết quả nghiên cứu trên. Theo nhiều nghiên cứu tăng khối mỡ nội tạng là nguyên nhân gây giảm mật độ xương, nghiên cứu của chúng tôi sử dụng BMI để chọn nhóm bệnh và nhóm chứng nên không đánh giá được chính xác lượng mỡ trong cơ thể nhất là khối mỡ nội tạng, có thể đây là nguyên nhân làm cho mật độ xương tại cổ xương đùi của nhóm bệnh cao hơn nhóm chứng.

\subsubsection{Phân loại mật độ xưong tại cột sống thắt lưng}

Chúng tôi nhận thấy tỷ lệ thiếu xương ở nhóm bệnh là $34,7 \%$ và nhóm chứng là 43,4\%. Tỷ lệ loãng xương nhóm bệnh là $45,6 \%$ và nhóm chứng là $48,3 \%$. Không có sự khác biệt về tỷ lệ thiếu xương và loãng xương giữa 2 nhóm $(\mathrm{p}>0,05)$.

Theo Kim K.C. và cộng sự tỷ lệ mỡ trong cơ thể và vòng bụng có liên quan đến giảm mật độ xương và là nguy cơ gãy xương cột sống. Kết quả nghiên cứu của của Kim K.C. khác với kết quả nghiên cứu của chúng tôi. Kết quả nghiên cứu khác có lẽ do số lượng cỡ mẫu khác nhau, cỡ mẫu trong nghiên cứu của Kim K.C. là 907 [9].

Nhìn chung tỷ lệ loãng xương và thiếu xương của nhóm chứng cao hơn nhóm bệnh, tuy nhiên sự khác biệt này không có ý nghĩa thống kê nên không thể kết luận gì về sự khác biệt này.

4.1.4. Phân loại mật độ xuơng tại cổ xương đùi

Nhóm bệnh tỷ lệ thiếu xương là 50,3\% và loãng xương là $27,9 \%$. Nhóm chứng tỷ lệ thiếu xương là $43,3 \%$ và loãng xương là $45 \%$ ( $\mathrm{p}<0,05)$. Phân loại mật độ xương tại cổ xương đùi chúng tôi nhận thấy có sự khác biệt về tỷ lệ thiếu xương và loãng xương giữa nhóm bệnh và nhóm chứng $(\mathrm{p}<0,05)$.

Tỷ lệ loãng xương và thiếu xương trong nghiên cứu của chúng tôi cao hơn kết quả nghiên cứu của tác giả Đặng Thị Hải Yến, tỉ lệ loãng xương đo ở vị trí cổ xương đùi ở phụ nữ $>50$ tuổi là $21 \%$ và tỉ lệ thiếu xương là $19 \%$ [10].

Tỷ lệ loãng xương ở nhóm chứng trong nghiên cứu này là $45 \%$, tương đương với tỷ lệ loãng xương theo chỉ số $\mathrm{T}$ của máy cung cấp trong nghiên cứu của Hồ Phạm Thục Lan [11] là 44\%, tương đồng này một phần là do chỉ số $\mathrm{T}$ của các máy Hologic sử dụng ở Việt Nam đều sử dụng giá trị tham chiếu của dân số Nhật Bản.

Tóm lại, khảo sát mật độ xương chúng tôi nhận thấy có sự gia tăng MĐX CXĐ ở nhóm bệnh so với nhóm chứng: nhóm bệnh là $(0,64 \pm 0,11)$ và nhóm chứng là $(0,60 \pm$ $0,12), \mathrm{p}<0,05$. Tỷ lệ thiếu xương và loãng xương của cả 2 nhóm như sau:

- CXĐ: Nhóm bệnh: Loãng xương 27,9\%, thiếu xương $50,3 \%$. Nhóm chứng: Loãng xương $45,0 \%$, thiếu xương $43,3 \%$.

- CSTL: Nhóm bệnh: Loãng xương 45,6\%, 
thiếu xương 34,7\%. Nhóm chứng: Loãng xương 48,3\%, thiếu xương 43,4\%

- Tỷ lệ loãng xương thấp hơn ở nhóm bệnh so với nhóm chứng, trong đó sự khác biệt của chỉ số T ở CXĐ $(27,9 \%$ và $45,0 \%), \mathrm{p}<0,05$.

\subsection{Dự báo nguy cơ gãy xương}

Việc sử dụng $\mathrm{MĐX}$ đơn độc để đánh giá nguy cơ gãy xương có độ đặc hiệu cao nhưng độ nhạy thấp. Độ nhạy thấp đồng nghĩa với việc xương có thể gãy xảy ở những phụ nữ chưa bị loãng xương.Vì thế $\mathrm{xu}$ hướng hiện nay không sử dụng $\mathrm{MĐX}$ đơn độc để chẩn đoán cũng như quyết định điều trị loãng xương [12].

Theo khuyến cáo của Hội loãng xương Mỹ (NOF: National Osteoporosis Foundation) các cá nhân loãng xương hoặc các cá nhân có tiền sử gãy xương hoặc các cá nhân thiếu xương nhưng có giá trị tiên lượng gãy xương toàn thân $\geq 20 \%$ hoặc giá trị tiên lượng gãy cổ xương đùi $\geq 3 \%$ được chỉ định điều trị [14].

Để tiên lượng tỉ lệ gãy xương toàn thân và gãy xương cổ xương đùi trong 10 năm của một cá thể, Tổ chức Y tế Thế giới (WHO) đã đưa ra mô hình FRAX là một phần mềm tính toán online kết hợp 12 yếu tố nguy cơ gãy xương. Đối tượng có giá trị tiên lượng gãy xương toàn thân $\geq 20 \%$ hoặc giá trị tiên lượng gãy cổ xương đùi $\geq 3 \%$ được xem là nguy cơ cao. Úng dụng quan trọng của mô hình FRAX là dự đoán nguy cơ gãy xương ở những bệnh nhân không loãng xương theo tiêu chí MĐX, tuy nhiên những người này có nguy cơ gãy xương cao. Lợi ích của mô hình FRAX là theo dõi và/hoặc điều trị loãng xương tốt hơn [15].

Theo kết quả Bảng 3.43 chúng tôi nhận thấy xác suất gãy xương toàn thân trong 10 năm $\geq 20 \%$ có 2 đối tượng, chiếm tỷ lệ $1 \%$ và xác suất gãy cổ xương đùi trong 10 năm $\geq 3 \%$ có 42 đối tượng, chiếm tỷ lệ $20,3 \%$.

Florence $\mathrm{A}$. Trémollieres và cộng sự nghiên cứu trên 2.651 phụ nữ Pháp mãn kinh và mãn kinh sớm, tuổi trung bình là $54 \pm 4$ năm, với thời gian nghiên cứu trung bình là $13,4 \pm 1,4$ năm. Các tác giả kết luận, trong dân số nghiên cứu mô hình FRAX có độ nhạy kém đối với dự đoán gãy xương và không có sự thay đổi đáng kể so với việc dự đoán gãy xương chỉ dựa vào mật độ xương cổ xương đùi đơn thuần. [16].

Johansson $\mathrm{H}$ và cộng sự nghiên cứu từ 10 đoàn hệ dân số tiềm năng, ghi nhận mật độ xương và các yếu tố nguy cơ , sử dụng mô hình FRAX với trị số tham chiếu của Vương quốc Anh. Các tác giả kết luận việc sử dụng FRAX kết hợp với mật độ xương làm tăng hiệu quả của việc của đánh giá nguy cơ gãy xương [17].

Pedrazzoni $M$. và cộng sự nghiên cứu trên 9586 phụ nữ Ý, tuổi trung bình 64,1 tuổi. Nghiên cứu sử dụng mô hình FRAX được điều chỉnh cho dân số Ý. Các tác giả kết luận, nguy cơ gãy xương toàn thân trong10 năm là $7,5 \%$ và $1,7 \%$ đối với gãy cổ xương đùi. $25 \%$ đối tượng có nguy cơ 10 năm $12,1 \%$ đối với gãy xương toàn thân và $\geq 4,1 \%$ đối với gãy cổ xương đùi. Nguy cơ gãy xương trung bình 10 năm tăng theo số lượng yếu tố nguy cơ thường gặp. Tuy nhiên, trong nghiên cứu $2 / 3$ các đối tượng tham gia nghiên cứu không có yếu tố nguy cơ gãy xương nào, việc đánh giá nguy cơ gãy xương chỉ dựa vào tuổi và mật độ xương [18].

Năm 2011, Kanis J.A và cộng sự đã đưa ra mô hình FRAX điều chỉnh theo liều corticoid đã và đang sử dụng. Các tác giả khuyến cáo đối với corticoid liều thấp $(<2,5 \mathrm{mg} /$ ngày prednison hoặc tương đương), xác suất gãy xương toàn thân giảm khoảng $20 \%$ tùy theo độ tuổi. Đối với liều trung bình (2,5-7,5 mg/ngày), giá trị FRAX chưa điều chỉnh có thể được sử dụng. Đối với liều cao (> 7,5 mg/ngày), xác suất gãy xương có thể được điều chỉnh tăng khoảng 15\% [19].

Nghiên cứu của chúng tôi sử dụng mô hình FRAX với giá trị tham chiếu dành cho người Thái Lan. Theo Bảng 3.42, tỷ lệ loãng xương chung tại $\mathrm{CXÐ} \mathrm{là} 32,9 \%$ và tỷ lệ có chỉ định điều trị LX theo khuyến cáo của NOF là $45 \%$. Chúng tôi nhận thấy có $12,1 \%$ (tiền sử gãy xương hoặc thiểu xương và nguy cơ cao) có chỉ định điều trị loãng xương theo NOF mặc dù không có loãng xương theo tiêu chí MĐX.

Một trong những vấn đề quan trọng của bác sĩ lâm sàng là nhận diện được những đối 
tượng có tăng nguy cơ gãy xương để điều trị và phòng ngừa trước khi gãy xương xảy ra, nhất là đối với những phụ nữ có tiền căn một lần gãy xương hoặc có bố mẹ có tiền căn gãy cổ xương đùi, hoặc có nguyên nhân gây loãng xương thứ phát thì tỉ lệ gãy cổ xương đùi sau và gãy xương toàn thân trong 10 năm ở những đối tượng này tăng cao. Vì thế không nên chỉ sử dụng mật độ xương để chẩn đoán và điều trị loãng xương mà nên kết với mô hình FRAX để dự đoán tỷ lệ gãy xương sau 10 năm để có hướng điều trị và phòng ngừa gãy xương sớm cho phụ nữ cao tuồi.

Mô hình FRAX có 12 yếu tố: tuổi , giới, cân nặng, chiều cao, tiền sử gãy xương, chỉ số $\mathrm{T}$, tiền sử gãy cổ xương đùi của bố hoặc mẹ, hút thuốc, uống rượu, viêm khớp dạng thấp, loãng xương thứ phát và sử dụng corticoid. Trong nghiên cứu của chúng tôi, những đối tượng có các yếu tố gây ảnh hưởng đến mật độ xương không nhận vào nghiên cứu nên tất cả các các đối tượng trong nghiên cứu đều không loãng xương thứ phát, không hút thuốc lá, không uống rượu, không tiền sử sử dụng corticoid và không viêm khớp dạng thấp, cho nên việc tiên lượng tỷ lệ gãy xương trong 10 năm theo mô hình FRAX trong nghiên cứu này có phần hạn chế.

\section{TÀI LIỆU THAM KHẢO}

1. Shanbhogue V.V., Finkelstein J.S., Bouxsein M.L., et al. (2016), “Association Between Insulin Resistance and Bone Structure in Nondiabetic Postmenopausal Women",J. Clin Endocrinol Metab. 2016, 101(8), pp. 3114-3122.

2. Ishii S., Cauley J.A., Crandall C.J., et al. (2012), "Diabetes and femoral neck strength: findings from the Hip Strength Across the Menopausal Transition Study", J Clin Endocrinol Metab., 97(1), pp.190-197.

3. Shin D., Kim S., Kim K.H., et al. (2014), "Association between insulin resistance and bone mass in men", $J$. Clin Endocrinol Metab., 99(3),pp. 988995.
4. Kanis J.A., McCloskey E.V., Johansson H., et al. (2010), "Development and use of FRAX in osteoporosis",Osteoporos Int., 21 Suppl 2,pp. S407-4013.

5. Kim K.C., Shin D.H., Lee S.Y., et al. (2010), "Relation between Obesity and Bone Mineral Density and Vertebral Fractures in Korean Postmenopausal Women",Yonsei Med J., 51(6), pp 857863.

6. Greco E.A., Fornari R., Rossi F., et al. (2010), "Is obesity protective for osteoporosis? Evaluation of bone mineral density in individuals with high body mass index", Int J Clin Pract,64(6), pp. 817- 820.

7. Søgaard A.J., Holvik K., Omsland T.K., et al. (2015), "Abdominal obesity increases the risk of hip fracture. A populationbased study of 43,000 women and men aged 60-79 years followed for 8 years. Cohort of Norway", J. Intern Med., 277(3), 306-317.

8. Andrea Palermo, Dario Tuccinardi, Giuseppe Defeudis, et al. (2016), "BMI and BMD: The Potential Interplay between Obesity and Bone Fragility", Int J Environ Res Public Health, 13(6), pp. 544.

9. Kim K.C., Shin D.H., Lee S.Y., et al. (2010), "Relation between Obesity and Bone Mineral Density and Vertebral Fractures in Korean Postmenopausal Women", Yonsei Med J., 51(6), pp 857863.

10. Đặng Thị Hải Yến, Đặng Văn Chính (2014), "Xác định tỷ lệ loãng xương và một số yếu tố liên quan ở phụ nữ $\geq 50$ tuổi tại Thành phố Vũng tàu, Bà Rịa Vũng Tàu", Y hoc TP. Hồ Chí Minh, Tập 18, Phu bản của số 6, tr. 134 - 140.

11. Ho-Pham L.T., Nguyen U.D., Pham H.N. (2011), "Reference ranges for bone mineral density and prevalence of osteoporosis in Vietnamese men and women", BMC Musculoskelet Disord., 12, pp. 182.

12. Compston J., Cooper A., Cooper C., et al. 
(2017), "UK clinical guideline for the prevention and treatment of osteoporosis", Arch Osteoporos, 12(1), pp. 43.

13. Nguyễn Thị Thanh Mai, Nguyễn Văn Tuấn, Hồ Phạm Thục Lan (2016), "Tác động của FRAX đến tỷ lệ điều trị loãng xương trong cộng đồng", Tạp chi Hội Loãng xuơng TP. Hồ Chí Minh và Hội Loãng xuơng Hà Nội Hội nghị khoa học thuờng niên và Kỷ niệm 10 năm ngày thành lập Hội, tr.39.

14. Cosman F., De Beur S.J., LeBoff M.S., et al. (2014), “Clinician's Guide to Prevention and Treatment of Osteoporosis", Osteoporos Int., 25(10), pp. 2359-81.

15. Bolland M.J., Siu A.T., Mason B.H., et al. (2011), "Evaluation of the FRAX and Garvan fracture risk calculators in older women",J. Bone Miner Res, 26(2), pp. 420-7.

16. Florence A. Trémollieres, Jean-Michel
Pouillès, Nicolas Drewniak, et al. (2010), "Fracture risk prediction using BMD and clinical risk factors in early postmenopausal women: sensitivity of the WHO FRAX tool ", J. Bone Miner Res., 25(5), 1002 -1009.

17. Johansson H, Kanis JA, Oden A., et al.(2009), "BMD, clinical risk factors and their combination for hip fracture prevention", Osteoporos Int., 20(10),pp.1675-1682.

18. Pedrazzoni M., Girasole G, Giusti A, et al. (2011), "Assessment of the 10-year risk of fracture in Italian postmenopausal women using FRAX®: a north Italian multicenter study", J. Endocrinol Invest., 34(11), pp. 386-391

19. Kanis J.A., Johansson H., Oden A., et al. ( 2011), "Guidance for the adjustment of FRAX according to the dose of glucocorticoids", Osteoporos Int., 22(3), 809-8016. 